\title{
UJI KETAHANAN GALUR-GALUR KENTANG TRANSGENIK HASIL TRANSFORMASI DENGAN GEN RB TERHADAP PENYAKIT HAWAR DAUN (PHYTOPHTHORA INFESTANS) DI KP PASIRSARONGGE, CIANJUR
}

\author{
Edy Listanto ${ }^{1}$, M. Herman ${ }^{1}, \&$ Eri Sofiari ${ }^{2}$ \\ ${ }^{1}$ Peneliti, Balai Besar Penelitian dan Pengembangan Bioteknologi dan Sumberdaya Genetik Pertanian \\ J1. Tentara Pelajar 3A Bogor, Jawa Barat 16111 \\ ${ }^{2}$ Peneliti, Balai Penelitian Tanaman Sayuran \\ Jl. Tangkuban Perahu No. 147 Lembang, Jawa Barat \\ E-mail: edy_listanto@yahoo.com
}

\begin{abstract}
Resistance test strains of transgenic potatoes transformed with RB gene to late blight (Phytophthora infestan) in KP Pasirsarongge, Cianjur. Potato late blight caused by Phytophthora infestans (P. infestans) (Mönt.) de Barry continues to be one of the most important crop diseases of all time. Genetic engineering of potato using $R B$ gene for resistant plant to this disease is the most effective and environmental friendly to prevent widespread of late blight. This research aims to perform resistance of transgenic potato lines containing $R B$ gene to lateblight ( $P$. infestans) in Pasirsarongge, Cianjur field trial station. The first generation of transgenic lines were planted on polybag containing soil:manures using randomized complete block design. Tested plant inoculation was done naturaly from inoculum source from border row (Granola) that has been planted at one month before. The symptom was observed at one month after planting and damage scoring was done every three days for five times. Twenty two transgenic lines of tested plant showed various resistance respond to late blight $(P$. infestans) attack. Three transgenic lines showed highly resistance to late blight ( $P$. infestans) were lines 11,24 , and 25 , one transgenic line has resistant level was line 6.
\end{abstract}

Key words: Granola, Late blight, Phytophthora infestans, $R B$ gene expression

\section{ABSTRAK}

Uji ketahanan galur-galur kentang transgenik hasil transformasi dengan gen RB terhadap penyakit hawar daun (Phytophthora infestan) di KP Pasirsarongge, Cianjur. Penyakit hawar daun pada tanaman kentang (Solanum tuberosum L.) yang disebabkan oleh Phytophthora infestans (P. infestans) (Mönt.) de Barry merupakan penyakit utama dan sangat merugikan. Perakitan tanaman kentang tahan mengandung gen $R B$ merupakan salah satu cara pengendalian penyakit hawar daun yang ramah lingkungan. Penelitian ini bertujuan untuk menguji ketahanan galur-galur kentang transgenik pembawa gen $R B$ terhadap penyakit hawar daun ( $P$. infestans) di KP Pasirsarongge, Cianjur. Umbi galur transgenik generasi $\mathrm{G}_{1}$, ditanam pada polybag mengandung media tanah:kompos dengan rancangan acak kelompok. Inokulasi tanaman uji secara alami dari sumber inoculum dari tanaman border (Granola) yang ditanam satu bulan sebelumnya. Gejala serangan diamati saat tanaman umur satu bulan dan dilakukan skoring tingkat serangan tiap 3 hari sekali dan pengamatan dilakukan sebanyak 5 kali. Dua puluh dua galur transgenik yang diuji menunjukkan variasi ketahanan terhadap serangan penyakit hawar daun $P$. infestans. Tiga galur transgenik menunjukkan sangat tahan terhadap serangan penyakit hawar daun ( $P$. infestans) di KP Pasirsarongge, Cianjur yaitu galur transgenik 11, 24 dan 25, serta satu galur transgenik tahan yaitu galur transgenik 6.

Kata kunci: ekspresi gen $R B$, Granola, hawar daun, Phytophthora infestans

\section{PENDAHULUAN}

Penyakit hawar daun pada tanaman kentang (Solanum tuberosum L.) yang disebabkan oleh Phytophthora infestans (P. infestans) (Mönt.) de Bary merupakan penyakit utama dan sangat merugikan pada tanaman kentang. Di Indonesia, kerugian yang disebabkan oleh penyakit hawar daun berkisar antara 10 sampai $100 \%$. Meskipun begitu, serangan patogen ini sangat dipengaruhi oleh tingkat infeksi, kelembaban udara diatas $95 \%$ dengan temperatur udara antara 12 $20^{\circ} \mathrm{C}$, dan kultivar yang digunakan (Suryaningsih, 1992; Sinaga et al., 1997; Purwanti, 2002). Pengendalian penyakit ini sering dilakukan dengan melakukan 
penyemprotan fungisida ke area pertanaman dengan frekuensi antara 20-30 kali per bulan. Penggunaan fungisida secara terus menerus dalam jangka waktu lama akan berpotensi merusak lingkungan.

Upaya pengendalian penyakit hawar daun yang ramah lingkungan telah lama dilakukan dengan menggunakan kultivar tahan. Perakitan varietas tahan dapat dilakukan dengan cara konvensional maupun nonkonvensional. Cara konvensional membutuhkan waktu lama dan sering mengalami kegagalan penyilangan disebabkan ketidakcocokan genetis dalam perbandingan jumlah nukleus dari endosperm kedua tetua yang disilangkan (Carputo et al., 2003). Kultivar-kultivar kentang yang telah dirakit selama ini memiliki ketahanan vertikal (ras spesifik) sehingga ketahanannya cepat patah karena sering dikendalikan secara monogenik dan sesuai dengan ras tertentu sehingga akan rentan bila ada serangan dari ras lain Suhardi (1979 dan 1982). Namun demikian, pemanfaatan tanaman kentang tahan penyakit hawar daun $P$. infestans sangat bermanfaat dalam menekan biaya operasioanal. Hasil studi sosial ekonomi (ex-ante) menginformasikan bahwa dalam pengendalian $P$. infestans petani melakukan penyemprotan fungisida antara 20-30 kali per musim tanam. Informasi lain yang diperoleh apabila petani menggunakan kentang varietas tahan terhadap $P$. infestans, maka petani dapat menghemat biaya penyemprotan antara $\mathrm{Rp}$ 4.097.625,-(50\%) sampai Rp 6.556.200,- (80\%) (Adiyoga, 2009)

Sifat ketahanan yang lebih diharapkan adalah ketahanan yang bersifat horisontal (non-spesifik ras). Sifat ketahanan ini dikendalikan secara poligenik sehingga dapat mengenal beberapa ras pathogen yang ada (Zhendong et al., 2004). Ketahanan horisontal (spektrum luas) sangat dibutuhkan untuk pengembangan tanaman kentang yang tahan terhadap beberapa ras $P$. infestans. Salah satu gen ketahanan yang mempunyai spektrum luas adalah gen $R B$ yang diisolasi dari kentang spesies liar $S$. bulbocastanum yang dikendalikan oleh gen tunggal (mayor) (Song et al., 2003). Gen $R B$ mengekspresikan terbentuknya protein NBS-LRR (efektor) yang berperan dalam pendeteksian protein patogen (elisitor) yang akan memicu gen-gen pertahanan yang ada di dalam tanaman (De Young \& Innes, 2006). Gen $R B$ tersebut mampu memberikan ketahanan lebih lama (durable) sehingga efektif digunakan dalam pemuliaan kentang untuk ketahanan terhadap penyakit hawar daun (Song et al., 2003; Colton et al., 2006). Salah satu kultivar yang telah dikembangkan dengan mentransfer gen $R B$ adalah varietas Katahdin dan telah menunjukkan sangat efektif menekan serangan semua ras $P$ infestans yang ada di Amerika dalam jangka lama (Song et al., 2003).
Gen $R B$ telah berhasil disisipkan ke genom kultivar Granola dan 50 galur transgenik terbukti telah mengandung gen $R B$ melalui analisis PCR (Listanto et $a l ., 2009)$. Keberhasilan transformasi gen $R B$ perlu diuji ekspresinya terhadap $P$. infestans. Penelitian ini bertujuan menguji ketahanan galur-galur kentang hasil transformasi yang mengandung gen $R B$ terhadap penyakit hawar daun ( $P$. infestans) di Kebun Percobaan Pasirsarongge, Cianjur.

\section{METODE PENELITIAN}

Tempat dan Waktu. Percobaan dilakukan di lapangan uji terbatas, KP Pasirsarongge, Cianjur, pada bulan Desember 2009 sampai dengan Februari 2010.

Penyiapan Tanaman Uji. Bahan tanaman yang diuji berasal dari umbi galur transgenik generasi $\mathrm{G}_{1}$, tanaman transgenik Katahdin SP951 (sebagai kontrol tahan) dan tanaman kentang Granola nontransgenik serta $S$. bulbocastanum. Setiap umbi ditanam pada kantong polybag yang berisi media tanah:kompos $=1: 1$ dengan jarak antar polybag $70 \mathrm{~cm}$ dan pemupukan menggunakan pupuk NPK dengan dosis sesuai budidaya tanaman kentang. Percobaan dirancang secara acak kelompok yang terdiri atas 3 ulangan dan tiap galur tanaman terdiri atas 3 tanaman per ulangan. Pengujian dilakukan berdasarkan metode Hansen et al. (2005). Bagian luar plot percobaan ditanami Granola nontransgenik sebagai infector row atau sebagai sumber inoculum. Sumber inokulum tanaman uji berasal dari tanaman border yang telah terserang secara alami sebelumnya. Gejala serangan diamati saat tanaman umur satu bulan dan dilakukan skoring tingkat serangan tiap 3 hari sekali dan pengamatan dilakukan sebanyak 5 kali. Skor pengamatan tingkat serangan penyakit menggunakan metode skoring dari Henfling (1979) yang dimodifikasi Halterman et al. (2008) (Tabel 1).

Kriteria penentuan tingkat ketahanan penyakit berdasarkan nilai area under disease progress curve (AUDPC) (Shanner \& Finney, 1977) sebagai berikut:

$$
\mathrm{AUDPC}=\frac{\left(\frac{\mathrm{D} 1+\mathrm{D} 2}{2} \times \mathrm{T}\right)+\left(\frac{\mathrm{D} 2+\mathrm{D} 3}{2} \times \mathrm{T}\right)+\left(\frac{\mathrm{D} 3+\mathrm{D} 4}{2} \times \mathrm{T}\right)}{\mathrm{n}-1}
$$

dengan:

$\mathrm{D}=\%$ tingkat serangan penyakit pada pengamatan berbeda $\left(\mathrm{D}_{1}, \mathrm{D}_{2}, \mathrm{D}_{3}, \mathrm{D}_{4}\right.$ dan $\left.\mathrm{D}_{5}\right)$; D: tingkat serangan penyakit pada pengamatan I - V

$\mathrm{T}=$ interval waktu antara dua pengamatan ( 3 hari) $\mathrm{n}=$ Jumlah pengamatan ( 5 pengamatan). 
Persen tingkat serangan (dihitung dengan rumus):

dengan:

$$
\mathrm{D}=\frac{\sum_{0}^{9} n_{i} \cdot v_{i}}{N . V} \times 100 \%
$$

$\mathrm{D}=\%$ tingkat serangan penyakit,

$\mathrm{n}_{\mathrm{i}}=$ jumlah tanaman dengan skor ke-i,

$\mathrm{v}_{\mathrm{i}}=$ skor ke-i,

$\mathrm{N}=$ jumlah tanaman contoh, dan

$\mathrm{V}=$ Nilai skor tertinggi.

Kriteria tingkat ketahanan (sangat tahan, tahan, agak tahan, dan rentan) ditentukan berdasarkan Tabel 2. Berdasarkan skor serangan dari setiap pengamatan pada tanaman uji dapat ditentukan laju perkembangan penyakit berdasarkan rumus yang diuraikan van der Plank (1963 dalam Kushalappa \& Ludwing, 1982) sebagai berikut:

$$
r=\frac{1}{t_{2}-t_{1}}\left(\ln \frac{x_{2}}{1-x_{2}}-\ln \frac{x_{1}}{1-x_{1}}\right)
$$

dengan:

$\mathrm{r}=$ laju perkembangan penyakit,

$\mathrm{t}=$ pengamatan ke-i, dan

$\mathrm{x}=$ skor serangan ke- $\mathrm{i}$

\section{HASIL DAN PEMBAHASAN}

Penyakit hawar daun ( $P$. infestans) pada tanaman kentang biasanya membutuhkan kondisi iklim lingkungan yang sesuai. Berdasarkan data di KP Pasirsarongge, Cianjur, kondisi lingkungan menunjukkan kelembaban udara cukup tinggi dengan rata-rata $89 \%$ antara bulan Januari 2009 - Februari 2009 dengan suhu udara rata-rata $18^{\circ} \mathrm{C}$ dan pada malam hari suhu mencapai $15^{\circ} \mathrm{C}$ (Anonim, 2009). Kondisi ini merupakan kondisi optimum untuk pembentukan sporangia dengan kelembaban nisbi yang tinggi (di atas $85 \%$ ) dan suhu udara $18-23^{\circ} \mathrm{C}$ (Hausladen \& München, 2006). Hasil pengamatan menunjukkan adanya massa putih yang merupakan kumpulan sporangia berada pada sisi bawah daun yang terinfeksi (Gambar 1).

Gambar 1 menunjukkan bahwa pada saat tersebut tanaman border yang merupakan varietas Granola tampak mengalami gejala penyakit yang sangat parah dan menunjukkan adanya massa sporangia yang berlimpah di sisi bawah permukaan daun. Beberapa galur transgenik yang diuji sudah mulai menunjukkan adanya serangan, namun tanaman transgenik Katahdin SP951 belum mengalami serangan yang berarti, dan ada tanaman spesies liarnya $S$. bulbocastanum yang merupakan sumber gen $R B$ menunjukkan kategori sangat sehat dan imun.

Tabel 1. Skoring serangan $P$. infestans di lapangan (Henfling, 1979)

\begin{tabular}{ccl}
\hline Skoring & Persentase daun terserang & \multicolumn{1}{c}{ Deskripsi } \\
\hline 0 & 0 & Tidak ada atau sangat sedikit jumlah nekrotik kecil dalam barisan \\
1 & $=10$ & Kurang dari 10\% daun mengalami hawar \\
2 & $10<\mathrm{X}=25$ & Bercak yang meluas/hawar mulai tampak dan dapat mencapai 25\% \\
3 & $25<\mathrm{X}=40$ & Hawar mencapai 26-40\% \\
4 & $40<\mathrm{X}=60$ & Hawar mencapai 60\% \\
5 & $60<\mathrm{X}=70$ & Setiap tanaman terinfeksi memiliki gejala hawar hingga 70\% \\
6 & $70<\mathrm{X}=80$ & Setiap tanaman terinfeksi dengan gejala hawar tertinggi (sekitar 80\%) \\
7 & $80<\mathrm{X}=90$ & Hanya daun pucuk masih tampak hijau \\
8 & $>90$ & Hanya tinggal sedikit daun pucuk yang masih tampak hijau \\
9 & 100 & Secara menyeluruh daun telah terserang \\
\hline
\end{tabular}

Tabel 2. Kriteria tingkat ketahanan berdasarkan nilai AUDPC (Sinaga, 2003)

\begin{tabular}{cc}
\hline Kategori & Nilai AUDPC \\
\hline Sangat tahan & $0,0-50,0$ \\
Tahan & $50,1-100,0$ \\
Agak tahan & $100,1-250,0$ \\
Rentan & $>250$ \\
\hline
\end{tabular}


Pengamatan di lapangan setelah tanaman berumur 1 bulan, tanaman uji sudah mulai menunjukkan adanya gejala serangan. Nilai $F_{\text {hitung }}$ berdasarkan hasil analisis varian dari rata-rata skor serangan antargalur pada pengamatan ke pertama sampai kelima (Tabel 3, Gambar 2) menunjukkan berbeda nyata dari setiap tanaman yang diamati.Pengamatan pertama menunjukkan skor terparah pada galur transgenik 9 dan 10 dengan nilai sebesar 1,56 dan 1,66 secara berturutan. Kedua galur tersebut menunjukkan tidak adanya beda nyata dalam tingkat serangan. Tanaman kontrol Granola menunjukkan skor
0,9 dan kontrol transgenik Katahdin SP951 dengan skor 0,45, sedangkan S. bulbocastanum PT29 menunjukkan skor 0,0 . Pengamatan berikutnya semakin menunjukkan peningkatan keparahan serangan patogen. Hal ini tampak pada pengamatan kedua dan seterusnya sampai dengan pengamatan kelima yang mengindikasikan pola keparahan yang bervariasi dan sangat berbeda nyata antargalur transgenik yang diamati. Penurunan tingkat ketahanan ini didukung hasil penelitian Millett et al. (2009) yang menunjukkan bahwa semakin tua tanaman maka ekspresi gen $R B$ menurun dan berakibat

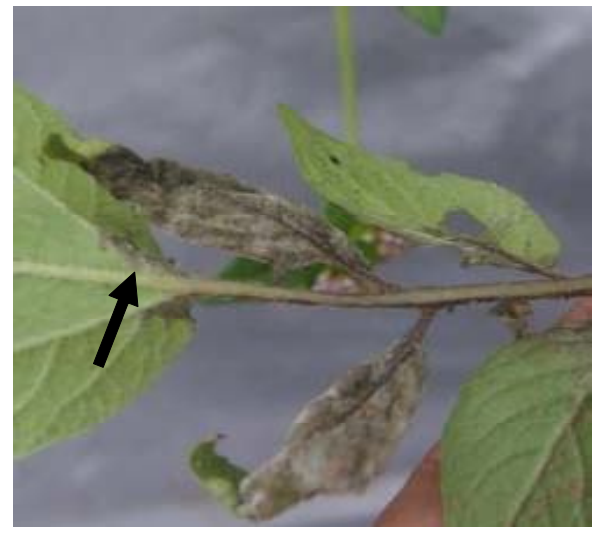

Gambar 1. Masa sporangia (tanda panah) pada daun kentang kultivar Granola non-transgenik yang terinfeksi P. infestans.

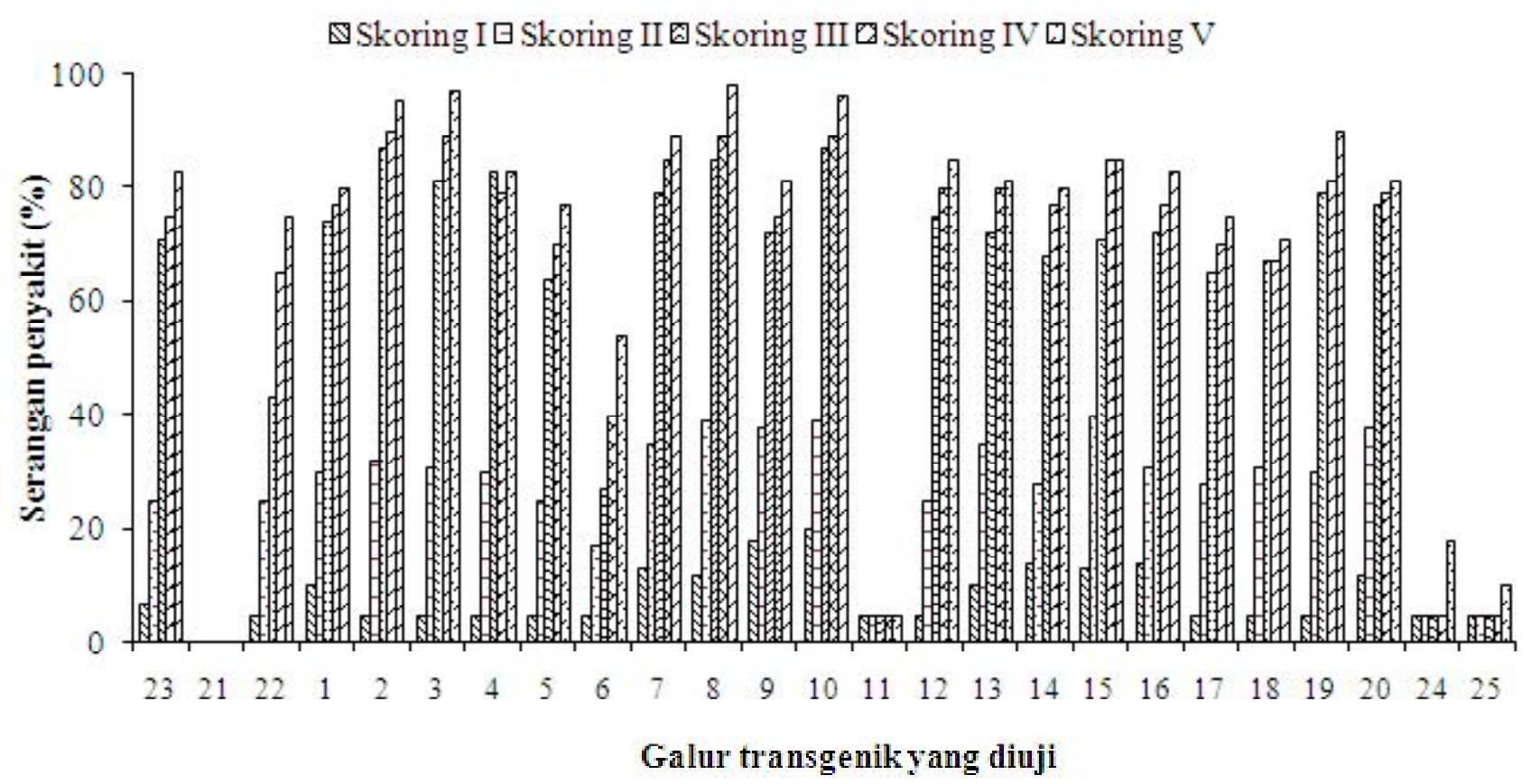

Gambar 2. Grafik perkembangan keparahan penyakit pada galur transgenik pembawa gen $R B$ generasi $\mathrm{G}_{0}$. Galur tanaman uji: 23 = Granola, $21=$ S. bulbocastanum, 22 = Katahdin SP951, dan galur transgenik 1-20, 24 , dan 25. 
Tabel 3. Rata-rata skor serangan $P$. infestans pada setiap tanaman uji generasi $\mathrm{G}_{1}$ dari setiap tahap pengamatan

\begin{tabular}{|c|c|c|c|c|c|}
\hline \multirow{2}{*}{ Galur uji } & \multicolumn{5}{|c|}{ Rata-rata kor serangan $P$. infestans pada setiap tahap pengamatan } \\
\hline & 1 & 2 & 3 & 4 & 5 \\
\hline Granola (23) & 0,90 abcd & $2,00 \mathrm{abc}$ & $5,11 \mathrm{abc}$ & $5,78 \mathrm{ab}$ & $6,22 \mathrm{a}$ \\
\hline S. bulbocastanum РT29 (21) & $0,00 \mathrm{~d}$ & $0,00 \mathrm{~d}$ & $0,00 \mathrm{e}$ & $0,00 \mathrm{~d}$ & $0,00 \mathrm{c}$ \\
\hline Katahdin SP951 (22) & $0,45 \mathrm{~cd}$ & $2,00 \mathrm{abc}$ & $3,11 \mathrm{~d}$ & $4,56 \mathrm{bc}$ & $5,33 \mathrm{ab}$ \\
\hline Galur transgenik 1 & $1,11 \mathrm{abc}$ & $2,90 \mathrm{a}$ & $5,33 \mathrm{abc}$ & $5,67 \mathrm{ab}$ & $6,00 \mathrm{a}$ \\
\hline Galur transgenik 2 & $1,00 \mathrm{abc}$ & $2,45 \mathrm{abc}$ & $6,67 \mathrm{a}$ & $7,00 \mathrm{a}$ & $7,45 \mathrm{a}$ \\
\hline Galur transgenik 3 & 0,78 abcd & $2,78 \mathrm{a}$ & $6,11 \mathrm{abc}$ & $6,78 \mathrm{a}$ & $7,22 \mathrm{a}$ \\
\hline Galur transgenik 4 & $0,78 \mathrm{abcd}$ & $2,56 \mathrm{abc}$ & $5,78 \mathrm{abc}$ & $5,90 \mathrm{ab}$ & $6,22 \mathrm{a}$ \\
\hline Galur transgenik 5 & $0,90 \mathrm{abcd}$ & $2,33 \mathrm{abc}$ & $4,33 \mathrm{~cd}$ & $5,22 \mathrm{ab}$ & $5,78 a b$ \\
\hline Galur transgenik 6 & $0,66 \mathrm{bcd}$ & $1,45 \mathrm{abcd}$ & $2,90 \mathrm{~d}$ & $3,11 \mathrm{c}$ & $3,67 \mathrm{~b}$ \\
\hline Galur transgenik 7 & $1,33 \mathrm{abc}$ & $2,68 \mathrm{ab}$ & $5,90 \mathrm{abc}$ & $6,22 \mathrm{ab}$ & $6,90 \mathrm{a}$ \\
\hline Galur transgenik 8 & $1,22 \mathrm{abc}$ & $2,90 \mathrm{a}$ & $6,44 \mathrm{ab}$ & $7,00 \mathrm{a}$ & $7,33 \mathrm{a}$ \\
\hline Galur transgenik 9 & $1,56 \mathrm{ab}$ & $2,78 \mathrm{a}$ & $5,22 \mathrm{abc}$ & $5,67 \mathrm{ab}$ & $6,11 \mathrm{a}$ \\
\hline Galur transgenik 10 & $1,66 \mathrm{a}$ & $2,90 \mathrm{a}$ & $6,67 \mathrm{a}$ & $6,90 \mathrm{a}$ & $7,33 \mathrm{a}$ \\
\hline Galur transgenik 11 & $0,44 \mathrm{~cd}$ & $0,78 \mathrm{dc}$ & $0,90 \mathrm{e}$ & $1,00 \mathrm{~d}$ & $1,00 \mathrm{c}$ \\
\hline Galur transgenik 12 & $1,11 \mathrm{abc}$ & $2,00 \mathrm{abc}$ & $5,33 \mathrm{abc}$ & $6,00 \mathrm{ab}$ & $6,45 \mathrm{a}$ \\
\hline Galur transgenik 13 & $1,11 \mathrm{abc}$ & $2,67 \mathrm{ab}$ & $5,22 \mathrm{abc}$ & $6,00 \mathrm{ab}$ & $6,11 \mathrm{a}$ \\
\hline Galur transgenik 14 & $1,22 \mathrm{abc}$ & $2,22 \mathrm{abc}$ & $4,78 \mathrm{abcd}$ & $6,00 \mathrm{ab}$ & $6,00 \mathrm{a}$ \\
\hline Galur transgenik 15 & $1,33 \mathrm{abc}$ & $3,00 \mathrm{a}$ & $6,00 \mathrm{abc}$ & $6,44 \mathrm{ab}$ & $6,67 \mathrm{a}$ \\
\hline Galur transgenik 16 & $1,22 \mathrm{abc}$ & $2,56 \mathrm{abc}$ & $5,22 \mathrm{abc}$ & $5,67 \mathrm{ab}$ & $6,22 \mathrm{a}$ \\
\hline Galur transgenik 17 & $0,56 \mathrm{~cd}$ & $2,33 \mathrm{abc}$ & $4,45 \mathrm{bcd}$ & $5,00 \mathrm{ab}$ & $5,45 \mathrm{ab}$ \\
\hline Galur transgenik 18 & $0,90 \mathrm{abcd}$ & $2,44 \mathrm{abc}$ & 4,66 abcd & $5,45 \mathrm{ab}$ & $5,56 a b$ \\
\hline Galur transgenik 19 & $0,78 \mathrm{abcd}$ & $2,56 \mathrm{abc}$ & $5,90 \mathrm{abc}$ & $6,00 \mathrm{ab}$ & $7,00 \mathrm{a}$ \\
\hline Galur transgenik 20 & $1,22 \mathrm{abc}$ & $2,78 \mathrm{a}$ & $5,67 \mathrm{abc}$ & $5,90 \mathrm{ab}$ & $6,44 \mathrm{a}$ \\
\hline Galur transgenik 24 & $0,45 \mathrm{~cd}$ & $0,78 \mathrm{~cd}$ & $0,90 \mathrm{e}$ & $1,00 \mathrm{~d}$ & $1,33 \mathrm{c}$ \\
\hline Galur transgenik 25 & $0,78 \mathrm{abcd}$ & $0,90 \mathrm{~cd}$ & $0,90 \mathrm{e}$ & $1,00 \mathrm{~d}$ & $1,00 \mathrm{c}$ \\
\hline$F_{\text {hitung }}$ & $2,12^{*}$ & $2,26^{*}$ & $10,84^{*}$ & $11,69^{*}$ & $10,28^{*}$ \\
\hline
\end{tabular}

Angka-angka pada lajur sama yang diikuti huruf sama menunjukkan tidak berbeda nyata berdasar uij Duncan pada $\alpha=0,05$.

penurunan tingkat ketahanannya terhadap serangan $P$. infestans.

Pengamatan keempat dan kelima menunjukkan nilai rata-rata keparahan penyakit di antara tanaman Granola, galur transgenik maupun kontrol transgenik dan S. bulbocastanum menunjukkan perbedaan yang sangat nyata. Perbedaan nilai keparahan penyakit antara galur transgenik kemungkinan berkaitan dengan tingkat ekspresi dari gen $R B$ yang ada di dalam masing-masing tanaman. Berdasarkan nilai keparahan penyakit dari setiap galur transgenik yang diuji menunjukkan peningkatan keparahan dari pengamatan pertama sampai dengan pengamatan kelima (Gambar 2).

Perkembangan nilai keparahan penyakit digunakan sebagai dasar menentukan tingkat ketahanan dari setiap galur yang diuji berdasarkan rumus AUDPC
(Shanner \& Finney, 1977). Dua puluh dua galur transgenik yang diuji menunjukkan tingkat ketahanan yang berbeda-beda (Tabel 4). Berdasarkan Tabel 4 tersebut terdapat tiga galur transgenik yaitu nomor 11, 24 dan 25 memiliki nilai AUDPC sebesar 5,00; 9,50 dan 7,50 (secara berurutan). Berdasarkan standar AUDPC maka ketiga galur transgenik tersebut masuk kategori sangat tahan. Satu galur transgenik yaitu galur transgenik 6 memiliki nilai 85,12 dan masuk kategori tahan. Galurgalur transgenik lain menunjukkan nilai AUDPC pada kategori agak tahan (Shanner \& Finney, 1977). Berdasarkan deskripsi tanaman kentang, kultivar Granola agak peka terhadap $P$. infestans, namun dengan adanya penyisipan gen $R B$ menunjukkan beberapa galur transgenik memiliki ketahanan terhadap P. infestans di KP-Pasirsarongge, Cianjur. Dengan 
Tabel 4. Tingkat ketahanan galur transgenik pembawa gen $R B$ generasi $\mathrm{G}_{1}$ terhadap serangan $P$. infestans berdasarkan nilai AUDPC dan nilai $r$ di KP Pasirsarongge, Cianjur

\begin{tabular}{|c|c|c|c|}
\hline Galur uji & Rerata laju serangan (r) & AUDPC & Kategori \\
\hline Granola non-transgenik (23) & 0,25 & 162,00 & AT \\
\hline S. bulbocastanum РT29 (21) & 0,00 & 0,00 & ST \\
\hline Katahdin SP951 (22) & 0,27 & 129,75 & AT \\
\hline Galur transgenik 1 & 0,36 & 169,50 & AT \\
\hline Galur transgenik 2 & 0,59 & 194,25 & AT \\
\hline Galur transgenik 3 & 0,57 & 189,00 & AT \\
\hline Galur transgenik 4 & 0,26 & 177,00 & AT \\
\hline Galur transgenik 5 & 0,27 & 150,00 & AT \\
\hline Galur transgenik 6 & 0,18 & 85,12 & $\mathrm{~T}$ \\
\hline Galur transgenik 7 & 0,27 & 187,50 & AT \\
\hline Galur transgenik 8 & 0,29 & 201,00 & AT \\
\hline Galur transgenik 9 & 0,19 & 175,87 & AT \\
\hline Galur transgenik 10 & 0,25 & 204,75 & AT \\
\hline Galur transgenik 11 & 0,06 & 5,00 & ST \\
\hline Galur transgenik 12 & 0,25 & 168,75 & AT \\
\hline Galur transgenik 13 & 0,23 & 174,37 & AT \\
\hline Galur transgenik 14 & 0,32 & 165,00 & AT \\
\hline Galur transgenik 15 & 0,23 & 183,75 & AT \\
\hline Galur transgenik 16 & 0,22 & 169,87 & AT \\
\hline Galur transgenik 17 & 0,27 & 152,25 & AT \\
\hline Galur transgenik 18 & 0,22 & 152,25 & AT \\
\hline Galur transgenik 19 & 0,31 & 178,12 & AT \\
\hline Galur transgenik 20 & 0,23 & 180,37 & AT \\
\hline Galur transgenik 24 & 0,10 & 9,50 & ST \\
\hline Galur transgenik 25 & 0,02 & 7,50 & ST \\
\hline
\end{tabular}

$\mathrm{ST}=$ sangat tahan, $\mathrm{T}=$ tahan, $\mathrm{AT}=$ agak tahan, $\mathrm{R}=$ rentan. (Kategori ketahanan berdasarkan Sinaga, 2003).

demikian, insersi gen $R B$ pada tanaman kentang kultivar Granola dapat meningkatkan ketahanan terhadap $P$. infestans ras Pasirsarongge, Cianjur dan diharapkan tahan terhadap beberapa ras yang ada di Indonesia serta bersifat durable resistance.

Berdasarkan perbandingan antara nilai AUDPC tanaman Granola yang terserang penyakit dan antara dengan galur transgenik yang menunjukkan kategori tahan dan sangat tahan tampak adanya peningkatan ketahanan (Tabel 4). Berdasarkan hasil uji lapangan, Granola menunjukkan nilai AUDPC sebesar 162.00 dengan kategori agak tahan. Hal ini dapat terjadi karena Granola yang berasal dari kebun percobaan kemungkinan sudah membawa inokulum yang terdapat pada umbinya atau sudah mengalami penurunan ketahanan terhadap ras $P$. infestans yang ada di kebun percobaan tersebut atau ras yang ada di tempat tersebut telah mengalami perubahan genetik. Granola yang digunakan sebagai tanaman kontrol negatif pada percobaan berasal dari umbi hasil kultur in vitro Granola L di Balitsa, Lembang. Selain itu, Granola yang berasal dari Lembang kemungkinan memiliki respon pertahanan yang berbeda dengan ras $P$. infestans yang ada di kebun percobaan Pasirsarongge, Cianjur sehingga masih memiliki ketahanan terhadap ras yang ada. Berdasarkan Setiawati et. al. (2007) disebutkan bahwa Granola L di Balitsa memiliki karakter agak peka terhadap $P$. infestans, hal ini menyebabkan munculnya respon agak tahan terhadap ras yang ada di kebun percobaan Pasirsarongge.

Berdasarkan intensitas serangan setiap waktu pengamatan dapat digunakan sebagai penentu laju (r) perkembangan penyakitnya (Sinaga, 2003). Besarnya nilai laju perkembangan penyakit juga dapat digunakan untuk menentukan tingkat ketahanan suatu tanaman terhadap serangan penyakit hawar daun (Tabel 4). Semakin kecil nilai laju (r) perkembangan penyakit menunjukkan bahwa tanaman lebih tahan dan sebaliknya 
lebih rentan. Hasil penghitungan pada galur transgenik 11, 24, dan 25 menunjukkan angka laju serangan sebesar 0,10 dan bila dilihat berdasarkan nilai AUDPC ketiga galur transgenik tersebut masuk kategori sangat tahan. Galur transgenik 6 menunjukkan nilai laju serangan sebesar 0,18 dan masuk kategori tahan. Tanaman Granola memiliki laju perkembangan penyakit sebesar 0,25 dan transgenik Katahdin SP951 memiliki nilai sebesar 0,27 dan berdasarkan nilai AUDPC keduanya masuk kategori agak tahan. Dengan demikian terbukti bahwa nilai laju perkembangan yang lebih besar menunjukkan penurunan tingkat ketahanan tanaman. Nilai laju perkembangan penyakit tersebut dapat digunakan untuk memprediksi tingkat penyakit pada waktu tertentu (Sinaga, 2003). Berdasarkan nilai
AUDPC dan laju serangan penyakit dapat ditentukan kriteria ketahanan seperti pada Tabel 5.

Gambar 3-5 menunjukkan perbedaan gejala serangan $P$. infestans saat mulai pengamatan sampai dengan saat akhir pengamatan dan panen umbi. Pada saat pengamatan awal tampak bahwa tanaman border (Granola) sudah menunjukkan keparahan yang jelas dibandingkan dengan tanaman uji. Kondisi ini dimaksudkan agar tanaman border dapat berfungsi sebagai sumber inokulan bagi tanaman uji. Serangan $P$. infestans tersebut didukung dengan kondisi lingkungan yang memenuhi syarat untuk penyebaran dan infeksi terhadap tanaman inang yaitu suhu antara $18-20{ }^{\circ} \mathrm{C}$ dengan kelembaban udara nisbi di atas $85 \%$ (Hausladen $\&$ München, 2006) dan suhu rata-rata di tempat

Tabel 5. Hubungan tingkat ketahanan berdasarkan nilai AUDPC dan laju perkembangan penyakit $\mathrm{r}$

\begin{tabular}{ccc}
\hline Kategori & Nilai AUDPC & Nilai $\mathrm{r}$ \\
\hline Sangat tahan & $0,0-50,0$ & $0,0<\mathrm{r}=0,10$ \\
Tahan & $50,1-100,0$ & $0,10<\mathrm{r}=0,18$ \\
Agak tahan & $100,1-250,0$ & $0,18<\mathrm{r}=0,59$ \\
Rentan & $>250$ & $\mathrm{r}>0,59$ \\
\hline
\end{tabular}
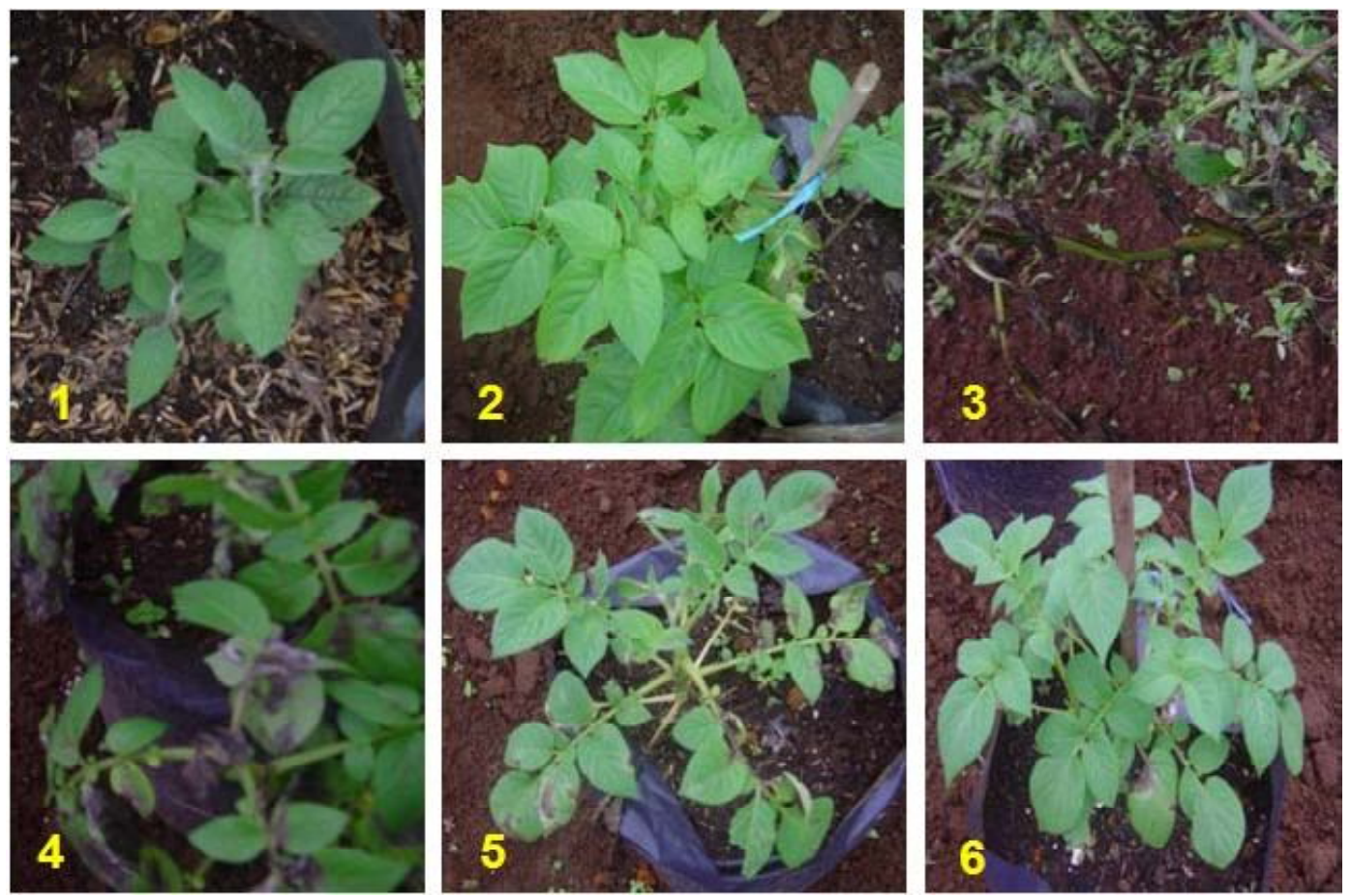

Gambar 3. Gejala serangan P. infestans pada tanaman uji umur 1 bulan setelah tanam. 1. S. bulbocastanum skor 0; 2. Transgenik Katahdin SP951 skor 1; 3. Border/Granola; 4 - 5. Granola non-transgenik; dan 6. Galur transgenik 9 skor 1. 

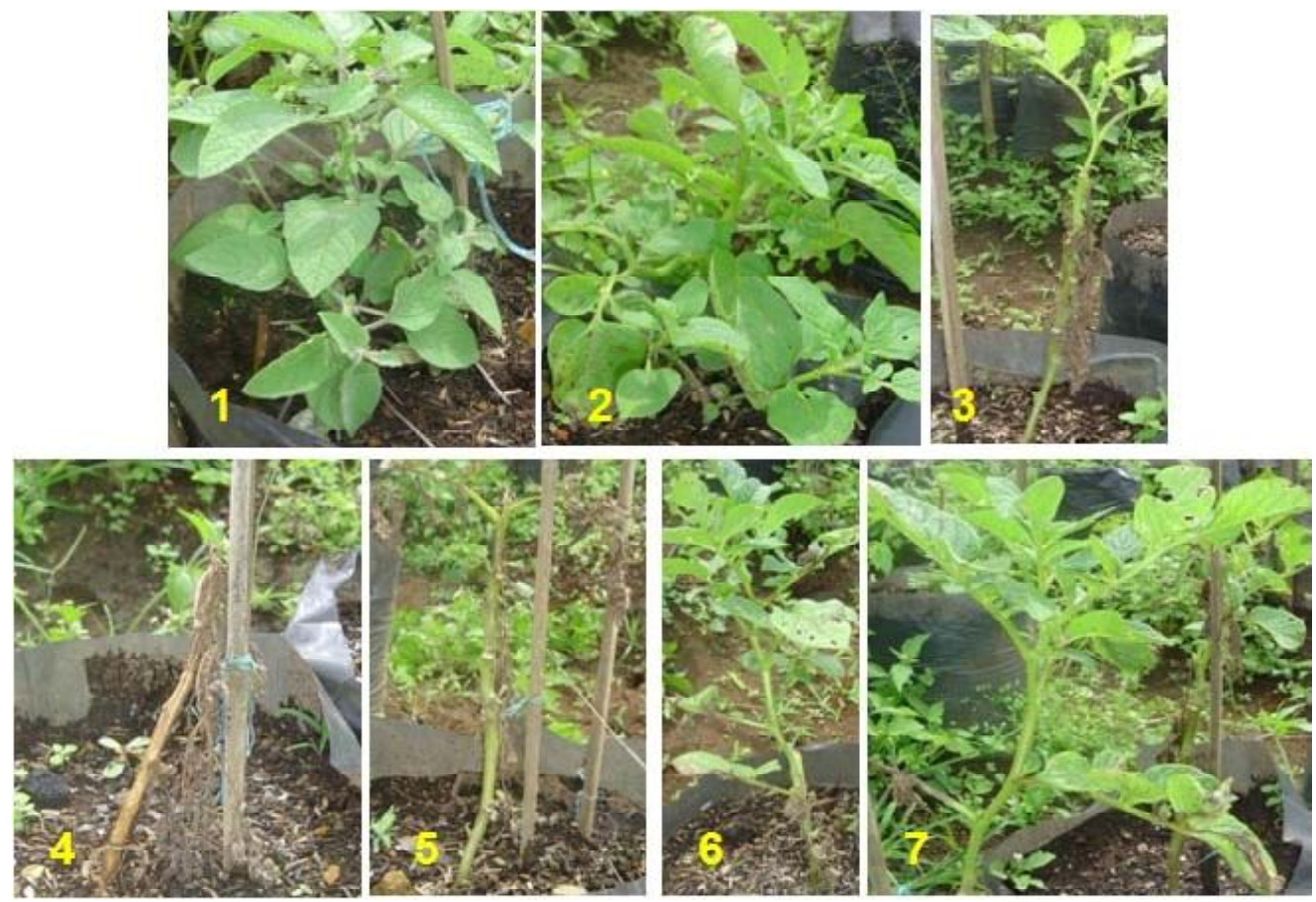

Gambar 4. Gejala serangan P. infestans pada tanaman uji (pengamatan akhir). 1. S. bulbocastanum skor 0; 2. Katahdin SP951 skor 1; 3. Granola non-transgenik skor 7; 4. Galur transgenik 2 skor 9; 5. Galur transgenik 12 skor 9; 6. Galur transgenik 6 Skor 1; dan 7. Galur transgenik 6 skor 2.
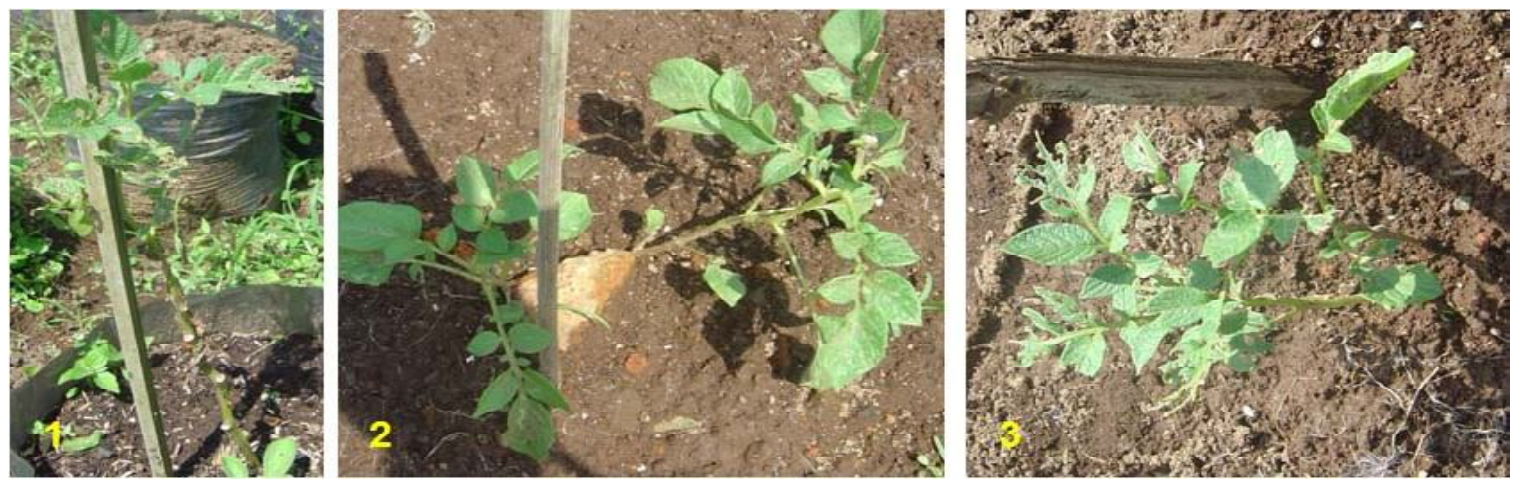

Gambar 5. Kondisi tanaman uji saat sebelum panen. 1. Galur transgenik 6; 2. Galur transgenik 24; dan 3. Galur transgenik 25.

percobaan menunjukkan angka yang memenuhi syarat yaitu $15^{\circ} \mathrm{C}$ (malam hari) dan $18^{\circ} \mathrm{C}$ (siang hari) dengan nilai RH rata-rata $89 \%$ (Anonim, 2009).

Keberhasilan merakit tanaman kentang Granola transgenik yang mengandung gen $R B$ tersebut akan memberikan keuntungan dalam produksi kentang. Hal ini disebabkan karena penggunaan biaya produksi mengalami penurunan dan petani akan memperoleh nilai tambah dari panennya. Selain itu, galur-galur transgenik ini juga lebih ramah lingkungan dan tidak berpengaruh buruk terhadap kesehatan biota tanah maupun manusia serta karena sumber gen $R B$ berasal dari kentang liar (S. bulbocastanum) maka galur-galur transgenik tersebut umbinya akan aman dikonsumsi (Cummins, 2006). 


\section{SIMPULAN}

Berdasarkan hasil percobaan yang dilakukan dapat disimpulkan bahwa 22 galur transgenik yang diuji menunjukkan variasi ketahanan terhadap serangan penyakit hawar daun $P$. infestans. Tiga galur transgenik menunjukkan sangat tahan terhadap serangan penyakit hawar daun (P. infestans) di KP Pasirsarongge, Cianjur yaitu galur transgenik 11, 24 dan 25, serta satu galur transgenik tahan yaitu galur transgenik 6 .

\section{DAFTAR PUSTAKA}

Adiyoga W. 2009. Costs and benefits of transgenic late blight resistant potatoes in Indonesia, In Norton, G.W. and Desiree M.H. (Eds.). Projected Impacts of Agricultural Biotechnologies for Fruits and Vegetables in the Philippines and Indonesia. ISAAA SEAsia Center, Los Banos Laguna 4030, Philippines. p. 86-104.

Anonim. 2009. Buletin Evaluasi Hujan Januari 2009 dan Prakiraan Hujan Maret 2009, Propinsi Jawa Barat. MBG, Stasiun Klimatologi Darmaga, Bogor.

Carputo D, Frusciante L, \& Peloquin SJ. 2003. The role of $2 \mathrm{n}$ gametes and endosperm balance number in the origin and evolution of polyploids in the tuberbearing Solanums. Genetics 163: 287-294.

Colton LM, Groza HI, Wielgus SM, \& Jiang J. 2006. Marker-assisted selection for the broad-spectrum potato late blight resistance conferred by gene $R B$ derived from a wild potato species. Crop Sci. 46: 589-593.

Cummins J. 2006. Genes from a wild plant Solanum bulbocastanum used to resist potato blight fungus, Biographical information. p. 1-6.

DeYoung BJ \& Innes RW. 2006. Plant NBS-LRR proteins in pathogen sensing and host defense. Nat. Immunol. 7(12): 1243-1249.

Halterman DA, Kramer LC, Wielgus S, \& Jiang J. 2008. Performance of transgenic potato containing the late blight resistance gene RB. Plant Dis. 92(3): 339-343.

Hansen JG, Koppel M, Valskyte A, Turka I, \& Kapsa J. 2005. Evaluation of foliar resistance in potato to Phytophthora infestans based on an international field trial network. Plant Pathol. 54: 169-179.
Hausladen H \& München TU. 2006. Phytophthora infestans: A pathogen of global importance. Courier, Center of Life and Food Sciences, Weihenstephan, Germany.

Henfling JW. 1979. Late blight of potato. Tech. information Bull. IPC, Lima, Peru, p.13.

Kushalappa AC \& Ludwig A. 1982. Calculation of apparent infection rate in plant siseases: development of a method to correct for host growth. Phytopathology 72(10):1373-1377.

Listanto E, Wattimena GA, Armini NM, Sinaga MS, Sofiari E, \& Herman M. 2009. Regenerasi beberapa kultivar kentang dan transformasi kentang dengan gen $R B$ melalui Agrobacterium tumefaciens. J. Hort. 19(2): 137-147.

Millett BP, Mollov DS, Iorizzo M, Carputo D, \& Bradeen JM. 2009. Changes in disease resistance phenotypes associated with plant physiological age are not caused by variation in $R$ gene transcript abundance. MPMI 22(3): 362-368. Doi:10.1094/ MPMI -22-3-0362.

Purwanti H. 2002. Penyakit hawar daun [Phytophthora infestans (Mont.) de Bary] pada kentang dan tomat: identifikasi permasalahan di Indonesia. Buletin AgroBio 5(2): 67-72.

Shanner G. \& Finney RF. 1977. The effect of nitrogen fertilization on the expression of slow mildewing resistance in Knox Wheat. Phytopathol. 67: 10511056.

Sinaga A, Budiman, Susi M, Sukmaya S, Djoko RD, Mei, Sudjoko S, \& Dimyati A. 1997. Potato cultivation (in Indonesia). Assessment Institute for Agriculture Technology.

Sinaga MS. 2003. Dasar-dasar Ilmu Penyakit Tumbuhan, Seri Agriteks. Penebar Swadaya, Cimanggis, Depok.

Setiawati W, Murtiningsih, T. Handayani, \& G.A. Sopha. 2007. Katalog Teknologi Inovatif Sayuran. Balai Penelitian Tanaman Sayuran. H1m.13. website.www.balitsa.or.id.

Song J, Bradeen JM, Naess SK, Raasch JA, Wielgus SW, Haberlach GT, Liu J, Kuang H, AustinPhillips S, Buell CR, Helgeson JP, \& Jiang J. 2003. Gene $R B$ cloned from Solanum bulbocastanum confers broad spectrum resistance to potato late blight. PNAS 100: 9128-9133. 
Suhardi. 1979. Penelitian pendahuluan beberapa ras fisiologi dari Phytophthora infestans pada tanaman kentang. Prosiding konggres V dan seminar ilmiah PFI, Malang 18-20 Januari. $6 \mathrm{hlm}$.

Suhardi. 1982. Beberapa aspek ekologi Phytophthora infestans dan respon tanaman kentang terhadapnya. Disertasi. Program Pascasarjana IPB, Bogor. Tidak dipublikasikan.
Suryaningsih, E. 1992. Pengujian efikasi fungisida Trimangol $80 \mathrm{WP}$ terhadap penyakit busuk daun (Phytophthora infestans) pada tanaman kentang. Buletin Penelitian Hortikultura 24(1): 92-98.

Zhendong T, Conghua X, \& Cheng H. 2004. Advance in molecular mechanism of potato resistance to Phytophthora infestans. World Potato Congress, 11 August 2004. 